\title{
DEISME: DARI EDWARD HERBERT SAMPAI DAVID HUMES
}

\author{
Shofiyullah Muzammil \\ Fakultas Ushuluddin dan Pemikiran Islam UIN Sunan Kalijaga \\ Yogyakarta
}

\begin{abstract}
Abstrak: Tulisan ini membahas tiga hal penting terkait dengan deisme, terutama deisme yang berkembang di Inggris. Pertama, munculnya deisme yang dimulai dengan gagasan Edward Herbert di tahun 1624, sebagai konsekuensi dan pengaruh situasi dan kondisi saat itu. Kedua, tumbuh suburnya deisme setelah pergantian abad ke-17, terutama karena pengaruh filsafat yang dikembangkan John Locke. Ketiga, merosotnya deisme dengan cepat pada pertengahan tahun 1700-an yang disebabkan oleh pemikiran skeptisisme David Humes. Tulisan ini dimulai dengan penjabaran pengertian deisme, karakteristik, dan perkembangan historis deisme, yang diikuti dengan penjelasan tentang latar belakang utama yang mempengaruhi kemunculannya. Selanjutnya, tulisan ini akan beranjak pada tokoh-tokoh deisme dan gagasannya yang meliputi tiga masa yang berbeda: masa perintisan dari Herbert sampai Blount (1624-1695); masa kejayaan dari Toland hingga Tindal (1696-1741); dan era kemunduran dari Annet sampai ke Bolingbroke (1742-1770).
\end{abstract}

Kata kunci: Deisme, Natural Religion, Revolusi Ilmiah, Reformasi Kristen

\section{Pendahuluan}

Deisme adalah istilah yang biasanya digunakan untuk mendeskripsikan pandangan-pandangan religius non-ortodoks yang berhubungan dengan beberapa penulis Inggris abad ke-17 dan ke18 dimulai dengan Edward Herbert, Lord of Cherbury dan berlanjut pada Charles Blount, John Toland, Anthony Collins, dan Matthew Tindal. ${ }^{1}$ Deisme adalah suatu gerakan atau sistem berpikir atau paham yang mendukung agama alam (natural religion),

${ }^{1}$ Walter Elwell (ed.), Evangelical Dictionary of Theology (Grand Rapids: Baker, 1984), hlm. 304. 
menekankan pada aspek moralitas, akan tetapi menyangkal intervensi Tuhan Sang Pencipta dalam hukum alam. Dengan kata lain, deisme meyakini bahwa Tuhan telah menciptakan alam semesta beserta hukum-hukumnya, setelah itu alam berjalan sesuai kaidah hukum yang telah ditetapkan itu tanpa sama sekali ada campur tangan Tuhan. Tuhan betul-betul lepas tangan, dan alam sepenuhnya berjalan dengan hukumnya.

A. H. Strong, sebagaimana dikutip dalam Charles Hodge (1986), menggambarkan deisme sebagai, "the view that represents the universe as a self-sustained mechanism from which God withdrew as soon as he had created it" (terjemah bebasnya: pandangan yang merepresentasikan alam semesta sebagai mekanisme self-sustained dari Tuhan yang menarik diri segera setelah Dia menciptakan alam). ${ }^{2}$

Secara etimologis, kata deisme berasal dari bahasa Latin Deus yang berarti Tuhan. Sama dengan pengertian Theos dalam bahasa Yunani yang juga berarti Tuhan. Kata "theism" dalam bahasa Inggris dibentuk dari kata Theos dalam bahasa Yunani. Karena itu, sebelum abad ke-17, kata-kata "theism" dan "deism" dapat dipertukarkan penggunaannya dalam bahasa Inggris. Namun dalam perkembangannya, para filsuf dan teolog mulai membedakan pengertian kedua istilah tersebut, terutama pada akhir-akhir abad ke- $17 .^{3}$

Sebagian ahli (scholars) menggunakan istilah deisme di Inggris untuk menandakan bahwa deisme Inggris merupakan lawan dari atau berbeda dengan filsafat naturalisme Perancis. Meskipun pendapat ini tidak didukung semua ilmuwan, namun umumnya mereka sepakat bahwa "deisme" sudah mulai populer digunakan sejak sekitar tahun $1682 .{ }^{4}$

${ }^{2}$ Charles Hodge, Systematic Theology (Grand Rapids: Eerdmans, 1986), hlm. 414.

${ }^{3}$ John Orr, English Deism: Its Roots and Its Fruits (Grand Rapids: Eerdmans, 1934), hlm. 13.

${ }^{4}$ Seorang teolog reformis asal Swiss bernamaViret, pada tahun 1563 menemukan naskah surat yang ditulis sahabat Yesus, yang di dalamnya menyebutkan bahwa ada orang-orang yang menamakan diri mereka kaum Deist. Lihat Ensiklopedi Webster No. 9, hlm. 35. Bandingkan dengan William Lane Craig, The Historical Argument for the Resurrection of Jesus During the Deist Controversy (Lewiston, England: Edwin Mellen Press, 1985), hlm. 72 . 


\section{Gagasan Pokok Deisme}

Deisme memiliki kesamaan dengan teisme, panteisme, dan politeisme dalam hal bahwa mereka masih mempercayai adanya Tuhan, sebagai lawan dari ateis yang sama sekali anti-Tuhan. Akan tetapi deisme memiliki karakteristik sendiri yang berbeda dengan paham ketuhanan lainnya. Kaum Deis percaya kepada Tuhan, tetapi mereka tidak memiliki seperangkat sistem kepercayaan formal atau sistem peribadatan kepada Tuhan. Kaum Deis biasanya disebut sebagai penganut agama alam (natural religion), yang mengakui pengetahuan religius yang diterima semata-mata melalui akal, sebagai lawan dari pengetahuan religius yang diperoleh melalui wahyu atau dogma keagamaan. Karakteristik deisme lainnya adalah mereduksi fungsi Tuhan di dalam penciptaan alam semesta hanya pada penyebab pertama itu saja, dan tidak ada keterlibatan lebih lanjut. Kau Deis biasanya menolak doktrindoktrin agama, seperti Tritunggal, inkarnasi, otoritas dan orisinalitas kitab suci, taubat, keajaiban/mukjizat, dan tindakan yang bersifat gaib dalam sejarah. ${ }^{5}$

Umumnya para ahli merumuskan lima prinsip dasar dalam deisme: (1) Tuhan itu ada (belief in the existence of the Deity/God), (2) Tuhan hendaknya disembah (the obligation to revere God), (3) melakukan kebaikan adalah ibadah paling utama kepada Tuhan (that virtue and piety are the chief parts of divine worship), (4) setiap orang pasti pernah melakukan kejahatan dan adalah wajib untuk menyesali perbuatan mereka (the obligation to repent of sin and to abandon it), (5) dan kelak mereka akan menerima penghargaan atau hukuman setelah mati (Good works will be rewarded and punishment for evil both in life and after death). ${ }^{6}$ Charles Hodge menyebut lima doktrin ini dengan "the confession of Faith of all Deists."

Dengan kelima prinsip di atas, kaum Deis menolak model agama yang mengatur secara ketat kehidupan para pemeluknya dengan ritual formal. ${ }^{8}$ Kaum Deis juga menyatakan penolakannya

${ }^{5}$ Elwell, Evangelical Dictionary, hlm. 304.

${ }^{6}$ Doktrin ini berdasarkan pada teori 5 azas kebenaran Herbert. Lihat James Livingston, Modern Christian Thought from the Enlightenment to Vatican II (New York: Macmillan, 1971), 14. Lihat juga Charles Hodge, Systematic Theology, hlm. 42.

${ }^{7}$ Hodge, Systematic Theology, hlm. 42.

${ }^{8}$ Orr, English Deism, hlm. 15-16. 
terhadap sistem kependetaan/kerahiban (clericalism) dalam agama. ${ }^{9}$ Bagi kaum Deis kepercayaan tertinggi adalah kepada alam. Deis meyakini bahwa kebenaran agama dapat ditemukan lewat penerapan akal dan pengamatan atas alam dunia. Deis umumnya menolak konsep wahyu gaib sebagai dasar kebenaran dogma atau agama.

Daniel L. Pals menyebutkan bahwa deisme berangkat dari keyakinan akan suatu agama yang bersifat tunggal, mendasar, dan orisinil yang muncul dari peradaban manusia. Yaitu, keyakinan akan adanya natural religion (agama yang bersifat alami/natural), agama yang meyakini adanya Tuhan Sang Pencipta alam semesta dan menetap hukum alam untuk mengaturnya; agama yang memberikan tuntunan moral bagi kehidupan manusia, serta menjanjikan kebahagiaan di akhirat kelak bagi manusia yang beramal saleh. ${ }^{10}$

Bagi penganut Deis, natural religion adalah bentuk keimanan paling awal dalam sejarah umat manusia, jauh sebelum gerejagereja memasuki corak pemikiran abad-abad sesudahnya dengan segala keajaiban, takhayul, ritual, pengorbanan, dan sistem kependetaan. ${ }^{11}$ Dengan kata lain, deisme menganggap natural religion sebagai bentuk paling awal dalam model keberagamaan manusia, yang kemudian berevolusi menjadi theisme dengan segala variannya, dari politeisme hingga monoteisme. Dengan pemikiran ini, deisme ingin menawarkan konsep agama kemanusiaan yang orisinil dan alami, agar manusia bisa hidup dengan keimanan tersebut dalam damai dan ketenangan dengan persaudaraan universal seluruh umat manusia. Konsep keimanan semacam ini, tentu sangat kontras dengan dogma keimanan yang dirumuskan oleh para pendeta atau teolog dan pemegang otoritas keagamaan lainnya dalam instusi agama formal, seperti Yahudi, Kristen, dan Islam.

\section{Ringkasan Jejak Historis Deisme}

Perkembangan Awal (pra-1624 M)

Ide awal deisme menurut para ahli kemungkinan dilahirkan di Perancis berdasarkan dokumen yang ditemukan Viret tahun 1563

${ }^{9}$ Ibid., hlm. 17.

${ }^{10}$ Daniel L. Pals, Dekonstruksi Kebenaran, Kritik Tujuh Teori Agama, Terj. Inyiak Ridwan Muzir, (Yogyakarta: IRCiSoD, 2001), hlm. 6-7.

${ }^{11}$ Ibid., hlm. 7 
M. ${ }^{12}$ Temuan Viret ini didukung oleh temuan lainnya tentang Deists oleh Penduduk Perancis bernama Philippe de Mornay di tahun $1581 \mathrm{M}$. Tentang asal usul natural religion sendiri, menurut Daniel L. Pals, para Deis berbeda pendapat. Ada yang menganggap berasal dari hewan, ada juga yang mengatakan bersumber dari rasa takut dan kebodohan manusia terhadap alam. ${ }^{13}$

Era Kebangkitan (1624 M-1695 M)

Formulasi pemikiran Deistik pertama kali disusun oleh seorang Inggris, Herbert Cherbury, dalam bukunya De Veritate, yang diterbitkan di Perancis tahun 1624. Mulanya, perkembangan deisme Inggris bergerak sangat pelan, hingga Blount pada tahun 1693 mulai menggencarkan paham deisme di Inggris. Kemudian John Locke, meskipun bukan seorang Deis, berhasil menancapkan pengaruh pemikiran teologi rasionalnya di Inggris melalui tulisan eseinya di tahun 1689, dan sebuah tulisannya yang berjudul Reasonableness of Christianity tahun $1695 \mathrm{M}$.

Puncak Kejayaan $(1696 \mathrm{M}-1741 \mathrm{M})^{14}$

Pengaruh pemikiran John Locke sangat besar terhadap perkembangan deisme di Inggris, terutama pada akhir abad ke-17. Para periode ini muncul tokoh-tokoh deisme yang menyebarkan pemikirannya menggunakan filsafat Locke. Misalnya, seorang tokoh utama deisme, John Toland, dalam karyanya Christianity Not Mysterious (1696), menggunakan kerangka rasionalisme Locke dalam menganalisis persoalan religius. Tokoh lainnya adalah Anthony Collin yang menulis Discourse on Free Thinking (1713) juga dengan mengadopsi argumentasi Locke. Collin juga menulis Ground and Reason (1724) yang menyerang kebenaran nubuat kitab Injil. Kemudian Thomas Woolston meluncurkan Six Discourses (1729) yang isinya menertawakan keajaiban, seperti soal kebangkitan Yesus. Puncaknya adalah karya Matthew Tindal Christianity as Old as the Creation (1730) yang menggangap doktrin Kristianitas sudah usang dan sebagai solusinya ia menyerukan kepada natural religion. Masa Kemunduran $(1742 \mathrm{M}-1770 \mathrm{M})^{15}$

${ }^{12}$ Viret menemukan sebuah dokumen surat yang pernah ditulis oleh sahabat Yesus. Di dalam surat itu, disebutkan bahwa ada sekelompok orang yang menganut paham Deisme. Lihat Craig, The Historical Argument, hlm. 252-268; Orr, English Deism, hlm. 18-19.

${ }^{13}$ Daniel L. Pals, Dekonstruksi Kebenaran, hlm. 8.

${ }^{14}$ Orr, English Deism, hlm 82-175; 
Deisme mulai kehilangan pengaruhnya ketika paham skeptisisme menyebar di Inggris dengan terbitnya buku Henry Dodwell Christianity Not Founded on Argument ( 1742), dan tulisan David Hume Essay of Miracles (1748) dan Natural History of Religion (1757). Buku-buku itu menggiring teologi menuju skeptisisme. Dalam tulisannya, Hume menggugurkan pandangan self-sufficiency dan pemikiran natural religion.

\section{Latar Belakang Kemunculan Deisme (pra-1624 M) ${ }^{16}$}

William Lane Craig mengidentifikasi beberapa faktor utama yang melatari kemunculan deisme. Di antaranya adalah ekspansi Eropa ke berbagai penjuru dunia, terjadinya revolusi ilmiah, munculnya kritisisme terhadap reliabilitas kitab Injil, dan implikasi sosial-religius dari gerakan Reformasi Kristen. ${ }^{17}$

\section{Ekspansi Eropa}

Ekspansi Eropa ke berbagai belahan dunia lain yang telah dimulai sejak tiga abad sebelum tahun 1750 M, menciptakan prakondisi kelahiran deisme. Rute Perjalanan Kolumbus yang mengenalkan Eropa ke Dunia Baru, peta pelayaran Magellan, kolonisasi Virginia ke wilayah Barat, dan munculnya keinginan besar untuk menguasai daerah Timur seperti India, Persia, serta wilayah-wilayah kekuasaan Islam secara tidak langsung mulai mengancam keyakinan ortodoksi Kristen tradisional. Perkenalan Eropa dengan negeri-negeri baru yang memiliki agama dan kebudayaan berbeda-beda mulai mengarahkan pada deisme dalam dua hal. Pertama, fenomena keragaman itu melahirkan pemahaman relativistik terhadap kepercayaan religius di seluruh dunia. Kedua, fenomena itu menjadikan klaim eksklusif Kristianitas terkesan tidak adil, sempit, dan kejam. ${ }^{18}$

\section{Revolusi Ilmiah}

Pencapaian temuan-temuan baru ilmiah di abad ke-17 mendukung terciptanya paham deisme, terutama kemajuan tiga cabang ilmu: astronomi, geologi, dan ilmu fisika, yang secara radikal mengubah pandangan tentang alam semesta. Di bidang astronomi, Copernicus mengenalkan teori heliosentrisnya dalam De Revolutionibus tahun 1543, Kepler memprakarsai teori tiga

\footnotetext{
15 Ibid.

${ }^{16}$ Orr, English Deism, hlm. 20-58.

${ }^{17}$ Craig, The Historical Argument, hlm. 82-175.

${ }^{18}$ Ibid., hlm. 82-92.
} 
hukum gerakan planet (three laws of planetary motion) tahun 1609, dan Galileo menerbitkan hasil penelitiannya tentang "bintik matahari" (sunspots) tahun 1613. Temuan-temuan ilmiah astronomi itu bertolak belakang dengan dogmatisme Gereja yang bersumber pada ajaran Kitab Injil. Lebih penting lagi, temuan ilmiah itu mulai menggeser cara pandang tentang hubungan Tuhan dan manusia, yang kemudian menjadi pijakan berpikir kaum Deis. ${ }^{19}$

Teori baru tentang fosil dan bukti-bukti geologis menunjukkan bahwa usia bumi sudah sangat tua. Bumi telah terbentuk milyaran tahun lalu. Sedangkan dalam pandangan gereja berdasarkan penafsiran terhadap Kitab Kejadian, usia bumi relatif muda, yaitu ribuan tahun yang lalu $( \pm 4004 \mathrm{SM}) .^{20}$

Revolusi ilmiah ketiga yang menjadi embrio lahirnya deisme adalah penemuan fisika Newtonian. Di tahun 1687, Isaac Newton menawarkan tiga hukum gerakan yang mendasari teori Mesin Dunia Newtonian (Newtonian world machine). Deisme mendasari pemikirannya pada teori ini, yaitu anggapan bahwa dunia ibarat sebuah mesin raksasa yang diatur oleh hukum tetap yang tidak mungkin berubah, yang didesain secara permanen oleh Sang Pencipta. Dalam konteks ini, deisme tidak mengakui adanya keajaiban di alam dunia, jika keajaiban itu dipahami sebagai sesuatu yang terjadi di luar hukum alam. Bahkan Tuhan sendiri tidak akan pernah melakukan intervensi terhadap hukum alam yang telah ditetapkannya. ${ }^{21}$

\section{Kritik terhadap Reliabilitas Injil}

Munculnya sikap kritis yang mempertanyakan reliabilitas kitab Injil semakin mengukuhkan keberadaan deisme. Adalah Hugo Grotius pada tahun 1640 yang memulai penerapan metode ilmiah dalam mengkaji Injil sebagai dokumen historis biasa. Studi kritis lainnya terhadap Injil dilakukan Thomas Hobbes dalam Leviathan (1651) dan Spinoza dalam Tractactus ( 1670). ${ }^{22}$

Gerakan Reformasi Kristen

Gerakan Reformasi dalam agama Kristen yang membuahkan aliran Protestan juga memiliki kontribusi besar terhadap lahirnya

\footnotetext{
${ }^{19}$ Ibid., hlm. 92-95.

${ }^{20}$ Ibid., hlm. 99.

${ }^{21}$ Ibid., hlm. 99-101.

${ }^{22}$ Ibid, hlm. 101-123.
} 
deisme. Gerakan Reformasi menggugat sikap kependetaan dan kepecayaan pada mistisisme gereja, serta menganjurkan penggunaan rasio dalam memahami agama. Kaum reformis juga mengkritik absolutisme dan otoritarianisme gereja dan elitnya yang memonopoli penafsiran kitab suci. Gerakan Reformasi ini membawa konsekuensi tumbuh suburnya gagasan yang mengarah pada deisme. $^{23}$

Di samping sebab-sebab di atas, ada juga beberapa faktor lain yang turut mendorong munculnya deisme. ${ }^{24} \mathrm{Di}$ antaranya penemuan mesin cetak di Gutenberg tahun 1450); kontroversi teologis seperti munculnya Gnostisisme, Anti-Trinitarianisme, Kristologis Non-Ortodoks, dan pengaruh pemikiran beberapa tokoh filsafat seperti Sokrates, Plato, Demokritus, Leucippus, Epicurus, Cicero, Plutarch, Celsus, Porphyry, dan Philostratus. ${ }^{25}$

\section{Tokoh-Tokoh Penting Deisme}

Era Kemunculan: dari Herbert sampai Blount (1624 M-1695 M) ${ }^{26}$

Fenomena deisme, termasuk di Inggris, sebenarnya bukan hal baru. Pola-pola berpikir deistik dan karakteristiknya dapat ditemukan di masa-masa silam sebelumnya. ${ }^{27}$ Meski demikian, Herbert Cherbury, walaupun bukan seorang Deis yang pertama kali, dianggap sebagai pelopor pemikiran deisme dalam tulisantulisannya. Karena itu, ia juga dijuluki sebagai "Father of English Deism", 28

Periode awal deisme di Inggris dimulai sejak Herbert mempublikasikan De Veritate (1624) dan ditutup dengan terbitnya tulisan Blount (1695). Tokoh lainnya yang mendukung pikiran deisme adalah Thomas Hobbes, Thomas Browne, John Tillotson, dan John Locke. Para tokoh ini sebenarnya tidak mengklaim diri mereka sebagai seorang Deis. Akan tetapi, pemikiran-pemikiran mereka yang menganjurkan teologi rasional sangat penting dan berpengaru besar terhadap orang yang ingin menjadi penganut deisme.

Edward Herbert (1583-1648) berasal dari keluarga bangsawan. Ia adalah seorang prajurit, diplomat Inggris untuk Perancis, ksatria,

\footnotetext{
${ }^{23}$ Ibid., hlm. 124-175.

${ }^{24}$ Orr, English Deism, hlm. 20-58.

${ }^{25}$ Livingston, Modern Christian Thought, hlm. 13.

${ }^{26}$ Orr, English Deism, hlm. 59-113.

27 Ibid.

${ }^{28}$ Craig, The Historical Argument, hlm. 72.
} 
dan juga ahli filsafat. Ia menulis De Veritate di Inggris dan menerbitkannya di Perancis tahun 1624. ${ }^{29}$

De Veritate pada dasarnya berbicara soal epistemologi. Dalam buku itu, Herbert membedakan antara kebenaran yang dapat diketahui melalui pengalaman dan kebenaran bawaan (innate truths) yang berlaku umum bagi semua orang. Herbert merumuskan lima azas kebenaran bawaan yang menjadi tanda Deism. ${ }^{30}$ Pandangan Herbert ini mempunyai pengaruh besar terhadap pemikiran sesudahnya, sehingga John Locke merasa penting untuk menyanggah teori kebenaran bawaan Herbert dalam satu bab tersendiri dalam eseinya. ${ }^{31}$

Pengaruh Pemikiran Non-Deis: Hobbes, Browne, Tillotson dan Locke

Thomas Hobbes (1588-1679) adalah seorang penulis produktif, ahli politik dan filsafat religius. Ia adalah pengagum Galileo dan Francis Bacon. ${ }^{32}$ Hobbes memang bukan seorqang Deis, ia lebih dekat disebut sebagai seorang materialis-atheit. ${ }^{33}$ Meski demikian, pemikiran epistemologis Hobbes sangat besar pengaruhnya terhadap kemunculan deisme Inggris. Di dalam Leviathan (1651) ia mengatakan, "...there is no conception in a man's mind, which hath not at first, totally, or by parts, been begotten upon the organs of sense." (tidak ada konsepsi dalam pikiran seseorang, yang tidak pada mulanya, secara keseluruhan, atau sebagian, yang diakibatkan [atas/ketika] rasa organ). ${ }^{34}$ Epistemologi Hobbes merupakan basis utamanya dalam mengkritik Injil. Orr menilai, Hobbes adalah kontributor utama pemikiran Deistik dalam mengkritik Injil dan doktrin-doktrin kegaiban atau mukjizat dalam agama Kristen. ${ }^{35}$

${ }^{29}$ Sidney Lee (ed.), Edward Herbert, Autobiography, (London: George Routledge and Sons, 1886), hlm. 132-133.

${ }^{30}$ P. H. Nidditch (ed.), Essays in Human Understanding, (Oxford: Oxford Press, 1975), vol. 1:iii, hlm. 15-19.

${ }^{31}$ Orr, English Deism, hlm. 71.

${ }^{32}$ Kenneth Scott Latourette, A History of Christianity, Vol. 2 (New York: Harper \& Row, 1975), hlm. 692

${ }^{33}$ David Berman, A History of Atheism in Britain: From Hobbes to Russell (London: Croom Helm, 1988), hlm. 57-67.

${ }^{34}$ Ibid.

${ }^{35}$ Orr, English Deism, hlm. 79. 
Tokoh Lain yang juga besar pengaruhnya terhadap pemikiran Deistik adalah Thomas Browne (1605-1682). Ia mengajukan sebuah pertanyaan terbuka tentang unsur-unsur agama yang misterius di dalam karyanya Religio Medici (1642). ${ }^{36}$ Hasilnya, Browne tidak mempercayai semua hal-hal misterius dalam agama, terutama Kristen, yang hal ini kemudian dikukuhkan dalam deisme.

Berikutnya John Tillotson (1630-1694), Uskup Canterbury, yang meskipun bukan seorang Deis, namun pemikirannya mempengaruhi deisme. Kegigihannya membela supernaturalisme rasional dalam gereja Kristen di Inggris, secara tidak langsung cenderung untuk mempromosikan aspek tertentu dalam deisme. Tillotson mereduksi agama Kristen ke dalam tiga prinsip agama alam yang serupa dengan lima azas kebenaran bawaan (innate truths) dari Herbert. Di tambah lagi, ia mengusulkan bahwa wahyu memperjelas kebenaran yang dibedakan oleh akal alami. Tillotson mengatakan, "Natural religion is the foundation of all revealed religion and revelation is designed simply to establish its duties." 38

Tokoh yang paling besar pengaruhnya terhadap deisme adalah John Locke (1632-1704), seorang pakar filsafat Inggris. Sedemikian penting pengaruh Locke terhadap keseluruhan pergerakan Deistic, sehingga Orr membagi dua periode penting deisme menjadi Post-Lockean dan Pra-Lockean. ${ }^{39}$

Ada dua karya penting Locke yang berdampak besar pada deisme, Essays in Human Understanding (1689) dan The Reasonableness of Christianity (1695). Locke menggugah kesadaran kaum Deis untuk membangun suatu epistemologi rasional dibanding mengikuti konsep "kebenaran bawaan" dari Herbert. ${ }^{40}$ Locke mengajukan beberapa gagasan yang kemudian dikembangkan lebih lanjut oleh kaum Deis. Locke menyuarakan sikap toleransi, anti-klerikalisme, merasionalisasi unsur-unsur misterius dalam agama, penafsiran kembali keajaiban alam, mengedepankan pendekatan etika dibanding pendekatan ritualistik

\footnotetext{
${ }^{36}$ Ibid., hlm. 83.

${ }^{37}$ Livingston, Modern Christian Thought, hlm. 15.

${ }^{38}$ Ibid., hlm. 23

${ }^{39}$ Orr, English Deism, hlm. 108.

${ }^{40}$ Ibid., hlm. 108, 115.
} 
agama, menghilangkan ketergantungan pada agama wahyu dan menggantinya dengan ketergantungan pada alam. ${ }^{41}$

Charles Blount: Revitalisasi Pemikiran Herbert

Charles Blount (1654-1693) adalah tokoh Deis yang menghidupkan kembali pemikiran Herbert. ${ }^{42}$ Karya utamanya dalam hal ini adalah Religio Laici (1683) dan Works (1695). Buku pertama berusaha mengidentifikasi apa sih kebaikan iman nonKristen dan apa kejelekan Iman Kristen? ${ }^{43}$ Blount melihat Kristianitas tidak jauh berbeda dengan agama pagan. ${ }^{44}$

Masa Kejayaan: dari Toland hingga Tindal (1696 M-1741 M)

Ada empat tokoh utama Deis yang mengantarkan deisme pada puncak kejayaannya di Inggris. Mereka adalah Toland, Collins, Woolston, dan Tindal. ${ }^{45}$ Pertama, John Toland ( 1670-1722) mulanya adalah penganut Katolik Roma yang kemudian menjadi liberal dan menganut deisme, dan berubah lagi menjadi pantheis. ${ }^{46}$ Karya pentingnya adalah Christianity Not Mysterious yang menjadi instrumen bagi pencapaian puncak deisme di Inggris. Buku itu berisi argumentasi Toland melawan misteri dan supernaturalisme di dalam keyakinan Kristen berdasarkan teori pengetahuan Locke yang sudah dimodifikasi. Toland menolak pandangan Locke yang membedakan antara wahyu yang berada di atas akal, dan oleh karena itu benar, dan wahyu yang bertentangan dengan akal, dan oleh karena itu salah. ${ }^{47}$ Tahun 1698, Toland menerbitkan Amyntor yang menggugat otoritas Kitab injil menuju ke agama naturalrasional. ${ }^{48}$

Setidaknya ada dua kontribusi penting Toland dalam mendukung deisme. Yaitu, Toland membantu membangun basis epistemologis deisme berdasarkan epistemologi yang digagas Locke dan sikap kritisnya terhadap kitab Injil. Dengan demikian, Toland membuat deisme semakin jelas dan terbuka sebagai paham yang anti-misteriusitas agama dan antu supernaturaliotas agama. ${ }^{49}$

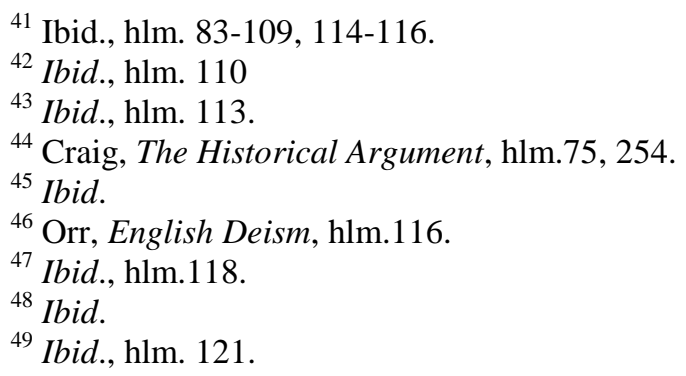


Kedua, Anthony Collins ( 1676-1729). Ia adalah sahabat karib Locke. Secara langsung Collins memang tidak memberikan kontribusi pemikiran bagi kemajuan deisme. Namun, dua karya penting Collins menyebabkan meningkatnya intensitas debat antara Deis dengan pihak ortodoks. Karyanya Discourse of Free-Thinking (1713) berisi argumentasi tentang toleransi beragama dan kebebasan berpikir. ${ }^{50}$ Dalam buku itu Collins juga memberikan argumentasi menentang reliabilitas Injil dan suparnaturalitas agama Kristen. Buku kedua Collins, The Ground and Reason of the Christian Religion (1724), tidak jauh berbeda dengan buku pertama. Isinya berupa argumentasi yang meragukan kredibilitas kitab suci dan penentangannya terhadap konsep kenabian. Argumen-argumen Collins dalam kedua buku itu menpatkan perlawanan keras dari kaum Ortodoks Kristen. Tercatat 55 tulisan yang merespons pemikiran Collins, baik yang pro maupun kontra. ${ }^{51}$ Inilah debat paling panas ketika itu.

Ketiga, Thomas Woolston (1669-1731). ${ }^{52}$ Ia adalah seorang penulis produktif dan "the most vitriolic of the Deists." ${ }^{53}$ Karya utamanya adalah Discourses on Miracles, dalam enam volume. Buku ini lebih banyak berisi serangan penulisnya terhadap tokohtokoh ajaib dan mistis yang terdapat dalam Injil. Woolston menggunakan metode alegori yang digagas Collins untuk melawan konsep keajaiban dan mukjizat, terutama soal kebangkitan Yesus. Menurut Woolston, peristiwa penyaliban Yesus itu hanya alegoiri. Sama seperti Collins, Woolston sebenarnya tidak menghasilkan pemirkiran baru dalam Derisme, namun karyanya itu mendapat banyak respons dari kaum Ortodoks melalui berbagai tulisan. ${ }^{54}$

Jika Toland memulai periode puncak deisme Inggris, maka Matthew Tindal (1655-1733) merepresentasikan "the culmination of the constructive phase of English Deism." 55 Karya utamanya adalah, Christianity as Old as the Creation (1730), yang oleh

\footnotetext{
${ }^{50}$ Ibid., hlm. 133-134.

${ }^{51}$ Ibid., hlm. 133-134.

${ }^{52}$ Craig, The Historical Argument, hlm.255-260; Orr, English Deism,

${ }^{53}$ Craig, Ibid., hlm. 255.

${ }^{54}$ Ibid.

${ }^{55}$ Livingston, Modern Christian Thought, hlm. 22.
} hlm. 138-140. 
Lucius Noack disebut, "Kitab Sucinya Kaum Deis." ${ }^{, 56}$ Di buku itu Tindal menulis:

"...no Religion can come from a Being of infinite Wisdom and Perfection, but what is absolutely perfect. Can, therefore, a Religion absolutely perfect, admit of any Alteration; or be capable of Addition, or Diminution; and not be as immutable as the Author of it? Can Revelation, I say, add any Thing to a Religion thus absolutely perfect, universal, and immutable?"57

Pemikiran Tindal dibangun di atas dua prinsip apriori. Pertama, Tuhan secara eternal adalah sama, Maha Baik dan Maha Bijaksana. Apa pun yang dimulai dengan kesempurnaan, meniscayakan dirinya sendiri sempurna. Dengan begitu, suatu agama yang sempurna tidak bisa diubah atau ditingkatkan atau dikurangi. Kedua, alam manusia selalu tidak dapat diubah dan yang sama dengan sendirinya. Karenanya, agama Tuhan yang sempurna harus membagikan kebenaran yang sama kepada semua orang terus menerus. $^{58}$

Tindal mengintegrasikan beberapa unsur-unsur tulisan Deistik sebelumnya ke dalam karyanya. Karena itu, ia betul-betul merepresentasikan pemikiran Deis. Ia mendukung konsep agama alami Herbert, menggunakan rasionalisasi Locke, dan beberapa serangan atas kitab suci. Ia mengadopsi pemikiran Blount yang menyamakan antara Kekristenan dan Paganisme, dan ia juga mengafirmasi metode alegori Collins terhadap konsep kenabian, dan menggunakan argumentasi yang sama dengan Woolston melawan keajaiban. Ia juga menganjurkan toleransi dan antiklerikalisme. Sebagai Deis ia memandang dirinya adalah reformis, dan bukan musuh bagi Kristianitas. ${ }^{59}$

Fase Kemunduran: dari Annet sampai Bolingbroke (1742-1770)

Ada beberapa faktor yang menyebabkan kemunduran deisme. Setelah pertumbuhan deisme yang lambat di era Herbert sampai Toland, lalu pesatnya perkembangan deisme dari masa Toland hingga Tindal, sampailah deisme pada titik jenuhnya. Pasca Tindal, tidak ada lagi pemikiran-pemikiran baru Deistik, seolah gagasan

\footnotetext{
${ }^{56}$ Orr, English Deism, hlm. 140.

${ }^{57}$ Livingston, Modern Christian Thought, hlm. 22.

58 Ibid.

${ }^{59}$ Orr, English Deism, hlm. 140-141.
} 
deisme sudah mencapai titik nadirnya. Pemikir deisme setelah Tindal hanya mengulang-ulang gagasan yang sama. Hingga akhirnya kemunculan skeptisisme radikal David Hume dan Henry Dodwell Jr. merontokkan sisa-sisa kekuatan deisme. Masyarakat umum pada waktu itu juga melihat deisme sebagai penanggung jawab maraknya imoralitas. Seiring dengan itu, muncul gerakan spiritual Wesley dan meningkatnya minat orang banyak pada dunia politik dan militer bersamaan dengan meluasnya kolonialisme Prancis, semakin mempercepat tamatnya riwayat deisme di Inggris. $^{60}$

Ada empat tokoh deisme pada fase kemunduran ini: Petrus Annet, Thomas Chubb, Conyers Middleton, dan Henry Bolingbroke. Petrus Annet (1693-1769) adalah seorang Deis tulen. Ia sangat membenci kependetaan dan Kitab Injil. Annet banyak mengkritik tokoh-tokoh yang disucikan dalam Injil, seperti Raja Daud dan Rasul Paul. ${ }^{61}$ Kemudian Thomas Chubb (1679-1747), salah seorang Deis radikal. Dalam tulisan yang diedarkannya, Chubb mengeluarkan pernyataan radikal dan provokatif. Ia mengatakan bahwa Yesus adalah seorang Deis. ${ }^{62}$

Conyers Middleton (1683-1750) adalah seorang pendeta/rabi, yang mengambil filsafat Deistik dan menerapkannya dalam penyelidikan kemukjizatan post-biblical dalam karyanya Miraculous Powers, Which Are Supposed to Have Subsisted in the Christian Church (1749). ${ }^{63}$ Terakhir, Henry Bolingbroke (16721751). Ia termasuk penulis prolifik. Ada lima volume buku yang diterbitkankannya untuk membela deisme. Sayangnya, tulisannya itu hadir di masa ketika deisme sudah mencapai titik jenuhnya. ${ }^{64}$

Di luar keempat tokoh tersebut, adalah pemikiran David Hume (1711-1776) yang berpengaruh besar terhadap kemunduran deisme. Tidak mudah untuk menguraikan pemikiran David Hume. Karena ia bukan seorang penulis yang konsisten. ${ }^{65}$ Satu sisi ia menampakkan dirinya senagai penganut Kristen Ortodoks, namun di sisi lain ia juga bersikap sama dengan kaum Deis, yaitu anti-

\footnotetext{
${ }^{60}$ Ibid., hlm.171-176.

${ }^{61}$ Ibid., 150-152.

${ }^{62}$ Ibid., 152-155.

${ }^{63}$ Ibid., 157-158.

${ }^{64}$ Ibid., 159-160.

${ }^{65}$ Ibid., hlm. 165.
} 
kependetaan, anti-kemukjizatan, anti-kitab suci. ${ }^{66}$ Karya utamanya yang mempengaruhi deisme adalah "Essays of Miracles" (1748) dan "Of the Idea of Necessary Connexion" yang keduanya dikompilasikan dalam An Enquiry Concerning Human Understanding dan Natural History of Religion (1757). Hume di satu sisi tampak seperti mendukung deisme, tetapi di sisi lain berbeda dengan mereka. Ia sependapat dengan deisme dalam hal pertentangannya melawan ortodoksi. ${ }^{67}$ Akan tetapi, Hume menolak gagasan "ide bawaan" (innate ideas )dari Herbert yang merupakan basis pemikiran agama natural, dan ia menolak keseluruhan gagasan tentang Tuhan sebagai Pencipta alam semesta. ${ }^{68}$

Semua tokoh Deis di atas adalah para pembela dan penyebar deisme di Inggri. Di luar itu, masih ada tokoh-tokoh lain yang mempopulerkan deisme di Prancis, Amerika, dan Jerman. Tokohtokoh deisme Prancis antara lain Voltaire, Denis Diderot, dan Rousseau. Sedangkan tokoh deisme Amerika di antaranya Tomas Jefferson dan Benjamin Franklin. Gotthold Lessing adalah tokoh utama deisme Jerman. ${ }^{69}$

\section{Kesimpulan}

Deisme di Inggris dimulai dengan gagasan Edward Herbert tahun 1624. Gagasan ini kemudian ditangkap dan diformulasikan kembali oleh Charles Blount tahun 1683 dan 1695. Selanjutnya, Herbert dengan natural religion dan teori kebenaran bawaannya menjadi basis perkembangan pemikiran deisme sampai masa kemunduran deisme pada pertengahan abad ke-18. John Locke memperkenalkan epistemologi baru yang kemudian diambil alih kaum Deis pada tahun 1689 dan 1695, berdasarkan pada fondasi empiris dan rasionalitas. Tahap berikutnya, John Toland memodifikasi pemikiran Herbert dan Locke untuk membantah halhal gaib dan memproklamirkan periode kemenangan deisme di Inggris. Kemudian, Matthew Tindal membawa gagasan deisme kepada puncak yang paling tinggi dengan memberikan tafsir baru atas pemikiran Toland pada tahun 1730. Tindal betul-betul menunjukkan pertentangannya melawan kitab suci. Deisme mulai kehilangan dayanya pada tahun 1740 setelah mendapat bantahan

\footnotetext{
${ }^{66}$ Berman, A History of Atheism, hlm. 101-105.

${ }^{67}$ Orr, English Deism, hlm. 165-171.

${ }^{68}$ Ibid., hlm. 175

${ }^{69}$ Daniel L. Pals, Dekonstruksi Kebenaran, hlm. 7.
} 
keras kaum Ortodoks dan serangan skeptisisme yang menyebar di Inggris. Joseph Butler dan beberapa tokoh ortodoks lainnya memberikan perlawanan sengit terhadap paham deisme. Namun lebih dari itu, Henry Dodwel (1742) bersama David Hume (1750) menebarkan argumentasi-argumentasi rasional yang meragukan keimanan terhadap agama, yang menyebabkan runtuhnya deisme.

\section{Daftar Pustaka}

Berman, David. 1988. A History of Atheism in Britain: From Hobbes to Russell. London: Croom Helm.

Craig, William Lane. 1985. The Historical Argument for the Resurrection of Jesus During the Deist Controversy. Lewiston, England: Edwin Mellen Press.

Elwell, Walter (ed.). 1984. Evangelical Dictionary of Theology. Grand Rapids: Baker.

Hodge, Charles. 1986. Systematic Theology. Grand Rapids: Eerdmans.

Latourette, Kenneth Scott. 1975. A History of Christianity. Vol. 2. New York: Harper \& Row.

Livingston, James. 1971. Modern Christian Thought from the Enlightenment to Vatican II. New York: Macmillan.

Nidditch, P. H. (ed.). 1975. Essays in Human Understanding. Oxford: Oxford Press.

Orr, John. 1934. English Deism: Its Roots and Its Fruits.Grand Rapids: Eerdmans.

Pals, Daniel L. 2001. Dekonstruksi Kebenaran, Kritik Tujuh Teori Agama. Terj. Inyiak Ridwan Muzir. Yogyakarta: IRCiSoD. Ensiklopedi Webster No. 9. 